BETTER OFF FORGETTING?

ESSAYS ON ARCHIVES, PUBLIC POLICY,

AND COLLECTIVE MEMORY

Throughout Canada, provincial, federal, and municipal archives exist to house the records we produce. Some conceive of these institutions as old and staid, suggesting that archives are somehow trapped in the past. But archives are more than resources for professional scholars and interested individuals. With an increasing emphasis on transparency in government and public institutions, archives have become essential tools for accountability.

Better Off Forgetting? offers a reappraisal of archives and a look at the challenges they face in a time when issues of freedom of information, privacy, technology, and digitization are increasingly important. The contributors argue that archives are essential to contemporary debates about public policy and make a case for increased status, funding, and influence within public bureaucracies. While stimulating debate about our rapidly changing information environment, Better Off Forgetting? focuses on the continuing role of archives in gathering and preserving our collective memory.

CHERYL AVERY is a professional archivist at the University of Saskatchewan Archives.

MONA HOLMLUND is an assistant professor in the Department of Art and Art History at the University of Saskatchewan. 
This page intentionally left blank 
EDITED BY CHERYL AVERY

AND MONA HOLMLUND

\section{Better Off Forgetting?}

Essays on Archives, Public Policy, and Collective Memory

UNIVERSITY OF TORONTO PRESS

Toronto Buffalo London 
(C) University of Toronto Press Incorporated 2010

Toronto Buffalo London

www.utppublishing.com

Printed in Canada

ISBN 978-1-4426-4167-9 (cloth)

ISBN 978-1-4426-1080-4 (paper)

$\infty$

Printed on acid-free, $100 \%$ post-consumer recycled paper with vegetablebased inks.

\section{Library and Archives Canada Cataloguing in Publication}

Better off forgetting?: essays on archives, public policy, and collective memory/edited by Cheryl Avery and Mona Holmlund.

Includes bibliographical references and index.

ISBN 978-1-4426-4167-9 (bound). - ISBN 978-1-4426-1080-4 (pbk).

1. Archives - Canada. 2. Archives - Access control. 3. Digital preservation.

4. Public records - Management. I. Avery, Cheryl II. Holmlund, Mona

CD3621.B47 $2010 \quad$ 025.17'14 C2010-902793-0

The authors gratefully acknowledge support from the University of Saskatchewan Publications Fund.

This book has been published with the help of a grant from the Canadian Federation for the Humanities and Social Sciences, through the Aid to Scholarly Publications Program, using funds provided by the Social Sciences and Humanities Research Council of Canada.

University of Toronto Press acknowledges the financial assistance to its publishing program of the Canada Council for the Arts and the Ontario Arts Council.

Canada Council for the Arts
Conseil des Arts du Canada

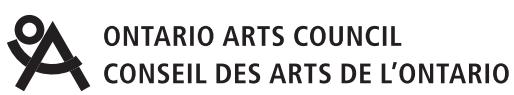

University of Toronto Press acknowledges the financial support of the Government of Canada through the Canada Book Fund for its publishing activities. 